Gunnar Ármannsson

lögmaður og fyrrum framkvæmdastjóri Læknafélags Íslands

\title{
Er hægt að bæta íslenska heilbrigðiskerfið?
}

Frá pví að ég fór að fylgjast náið með heilbrigðismálum, árið 2002, hefur svarið sennilega alltaf verið já. Ég man ekki eftir umræðunni öðru vísi en að pað sé alltaf eitthvað að. Eitthvað sem má bæta. En sennilega parf pað ekki að koma á óvart. Viðfangsefnin á sviðinu eru ærin og kröfurnar sem gerðar eru aukast frá einum tíma til annars. Рað parf ekki nema litla umhugsun til að átta sig á að pað er nánast innbyggt í kerfið að pað kallar á aukna fjármuni frá ári til árs. Aukinn heilbrigðiskostnaður er að sumu leyti ákveðið lúxusvandamál pví við sjálf aukum kröfurnar eftir pví sem tækninni fleygir fram og velmegunin verður meiri. Hvers kyns lífsstílssjúkdómar, til dæmis sykursýki, offita og fleira, auka álag á kerfið. Sums staðar eru pjóðir sem heild að eldast. Fólk lifir lengur og gerir meiri kröfur en ádur var til lífsgæða fram á efri ár. Frampróun í framleiðslu lyfja og tækja er dýr og kallar á aukið fjármagn. Pegar við heyrum af nýjum lyfjum og tækjum viljum við fá aðgang strax. Við viljum betri aðbúnað sjúklinga og starfsmanna. Petta viljum við allt og petta kostar.

En hvað er til ráða? Eigum við að reyna að gera sem minnst og búa við lítið breytt ástand til næstu 15 ára? Eigum við kannski að banna eða minnka einkarekstur í kerfinu? Eða eigum við kannski að auka hann? Eða gera eitthvað annað? Eigum við kannski að minnka Landspítala aftur? Opna nýjan Borgarspítala og nýtt Landakot? Eða eigum við kannski að „sleppa pessu lausu“ og láta kerfið sjálft um að próa sig án stefnumótunar og íhlutunar? Sumir hafa haldið pví fram að pað sé besta lausnin. Að minnsta kosti væri rétt að halda pólitískum stefnumótendum sem lengst frá. Peir hafi hvort sem er ekki skilað of góðu verki hingað til. Á pað hefur verið bent að ein ástæða pess að Hollendingar hafa allt frá árinu 2006 setið í toppsæti „Euro Health Consumer Index“ listans, sé sú að í Hollandi spili heilbrigðisstarfsfólk og samtök sjúklinga mun stærra hlutverk við stefnumótunina en á sér stað annars staðar í Evrópu.

Í Hollandi fór fram yfirveguð og vönduð stefnumótunarvinna áður en Hollendingar réðust í kerfisbreytingar hjá sér sem tóku gildi árið 2006. Fram að peim tíma fannst peim nálgun peirra með pví að byggja pjónustuframboðið á miðlægum ákvörðunum ekki skila nægilega góðum árangri. Pótt peim tækist að halda heilbrigðiskostnaði niðri til margra ára pá fannst peim lítil samsvörun í framboði og eftirspurn, ófullnægjandi samhæfing í kerfinu, takmarkað val sjúklinga og skortur á hvötum til að auka framleiðni.
Í stuttu máli færðu Hollendingar heilbrigðistrygginguna frá ríkinu og til tryggingarfélaganna. Petta gerðu peir með pví að setja skýran lagaramma um málaflokkinn pannig að í raun breytti pessi tilfærsla engu í réttindum sjúklinga. Рað sem peir náðu hins vegar fram var samkeppni á milli tryggingarfélaga sem keppast við að ná sem bestum samningum við veitendur pjónustunnar sem byggist bæði á gæðum og verði. Fyrir tryggingarfélögin skiptir engu máli hvort pjónustuveitandinn er einkarekinn eða rekinn af almannafé. Hagsmunirnir sem peim ber að verja eru alltaf hagsmunir sjúklinganna. Sá sem veitir bestu pjónustuna fyrir besta verðið er valinn. Petta veitir ríkinu fullkomið frelsi til að ákveða sjálft hvaða pjónustu pað vill veita pegnum sínum. Раð býr hins vegar alltaf við aðhald frá einkageiranum pannig að ef einkageirinn getur boðið jafngóða eða betri pjónustu á lægra verði er samið við einkaaðilann. Annars er pað einkaaðilinn sem verður undir í samkeppninni.

Pað má vel sjá fyrir sér að hér á landi sé hægt að fara svipaða leið. Раð parf einfaldlega að skoða vandlega og af yfirvegun hvað geti mögulega hentað og ekki er víst að öllum hugnist leið Hollendinga að færa sjúkratrygginguna til tryggingarfélaga á markaði. Рað má vel hugsa sér að hér á landi yrði pað hlutverk Sjúkratrygginga Íslands að sjá alfarið um að kaupa pjónustuna. Veitendur pjónustunnar geta pá verið hvort heldur sem er hið opinbera eða einkaaðilar.

Pegar kostir og gallar einkarekinna lausna eru ræddir er sjálfsagt að pað sé gert á opinskáan hátt og öllum steinum velt við. Раð gerðu Hollendingar og tóku sér góðan tíma. Úr pví að peim tókst jafn vel upp og raun ber vitni gæti verið full ástæða til að skoða vel aðferðafræði peirra. •að er eðlilegt að pað sé rætt hvort einkarekin pjónustu geti mögulega haft neikvæð áhrif á pjónustuframboð pess opinbera. Hvort heldur um er að ræða einstakar sérhæfðar sérgreinar, mögulegan mönnunarvanda pess opinbera og svo framvegis. Pessi umræða verður hins vegar alltaf erfið og bjöguð ef hún getur ekki farið fram undir öðrum formerkjum en peim að talsmönnum einkareksturs séu gerðar upp skoðanir og jafnvel annarlegar hvatir. Pað er nefnilega til í alvörunni fólk sem heldur að hægt sé að bæta íslenska heilbrigðiskerfið með pví „,að gera eitthvað annað“ - og að petta annað geti verið einkareknar lausnir. 